\title{
Gaming Tourism Boom, Foreign Currency Inflows, and Dutch Disease Effects: an Empirical Model for Macau
}

\author{
Susana Mieiro, Pedro Nogueira Ramos, and José Alves
}

\begin{abstract}
Although gaming tourism has been playing an important role in Macau's economy since the $19^{\text {th }}$ century, 2002 change in local gaming legislation (i.e., gaming liberalization) led Macau to a new gaming tourism era and also to the suspicion of Dutch Disease effects. Therefore, under a framework where $\mathbf{2 0 0 2}$ gaming liberalization is regarded as the trigger for the gaming tourism boom in Macau, we econometrically tested the impact of selected GT indicators on the domestic exports of goods and assessed the presence of the Dutch Disease phenomenon in Macau, effectively linking this concept with the territory's economic reality.

The understanding of the underlying phenomenon of Macau's economic reality is essential to design a suitable strategy to manage its potential long-run effects. In our view, suffering from the Dutch Disease should only represent a serious economic problem to Macau if the territory loses its gaming privileged position. Therefore, we consider that in order to adequately manage the Dutch Disease potential harmful effects priority should be given to applying the gaming tourism revenues in investments that aim the creation of lasting value in this region and contribute to its sustainable development, such as education and health.
\end{abstract}

Index Terms-Dutch disease, foreign currency inflows, gaming tourism, Macau.

\section{INTRODUCTION}

Known internationally as "Monte Carlo of the Orient" and "Las Vegas of the East", Macau has been associated with gaming activities since the $16^{\text {th }}$ century, although gaming was only legalized in 1847, as a form of diversifying this region's economic activities and of generating public revenues. After 2002, with the end of the monopoly gambling rights that had been granted since 1962 to S.T.D.M. ("Sociedade de Turismo e Diversões de Macau") [1], Macau entered into a new gaming tourism (GT) era.

The change in Macau's gaming legislation was followed by the arrival of new operators into local gaming business as well as by the growth of the former monopolist. This new GT era was marked by the entry on the scene of Western hotel and casino operators, which was particularly evident after 2004, when Venetian Macao (a casino owned by Las Vegas Sands Corp.) opened its doors to the public. Accordingly, the number of casinos increased considerably as they went from 11 in 2002 to 15 in 2004, and recently to 35 in the third

Manuscript received October 9, 2012; revised November 10, 2012.

Susana Mieiro is with the University of Saint Joseph, Macau S.A.R., People's Republic of China (e-mail: susana.mieiro@usj.edu.mo).

Pedro Nogueira Ramos is with the Group for Monetary and Financial Studies (GEMF), Faculty of Economics, University of Coimbra, Portugal (e-mail: pnramos@fe.uc.pt).

José Alves is with the University of Saint Joseph, Macau S.A.R., People's Republic of China (e-mail: jose.alves@usj.edu.mo). quarter of 2012 [2]. Moreover, the stock of Inward Direct Investment in Gaming, Hotels and Restaurants, adjusted by the implicit price deflator (year 2010=100) of Macau's Gross Domestic Product (GDP), grew 193\% from 2002 to 2010 (data sources: [3], [4]). This growth in GT offering encompasses, in our view, a supply shock in the GT sector.

On the other hand, in addition to 2002 change in local gaming legislation, in 2003, the Chinese central government removed existing barriers between Macau and Mainland China by introducing the "Free Travel Scheme" (or "Individual Visit" scheme - IVS), allowing individual visitors from a number of cities in Mainland China to travel to Macau (and to Hong Kong), and thus bringing an increasing number of visitors to Macau [5]. The number of total visitor arrivals grew $45 \%$ from 2002 to 2004, and $68 \%$ between 2004 and 2011. During this last period (2004-2011) the average weight of the visitors travelling to Macau under the IVS on total visitors to Macau was almost 25\%, evidencing the importance of the IVS implementation in the territory's GT increased demand (data sources: [6], [7]).

Nonetheless, the contribution of inbound visitors to the expansion of Macau's GT demand resides in their spending in the territory. Effectively, Macau's exports of services resulting from the expenditure of non-residents in the domestic market, in chained (2010) dollars, grew $66 \%$ between 2002 and 2004, and 245\% between 2004 and 2011 (data source: [4]). As a result, besides the supply shock in the GT sector, which was caused by the change in Macau's gaming legislation, we also consider that the GT sector in Macau felt the impact of a demand shock, due to the increased visitor arrivals to Macau, after 2003, and their growing spending in the territory.

Both these shocks in supply and demand of GT services characterize, in our view, the GT boom in Macau, which brought into the territory considerable flows of foreign currency through Foreign Direct Investment (FDI) and GT revenues. The foreign exchange surplus resulting from the exports of a booming sector is often related, in economic literature, with harmful consequences for the traditional industrial sector. This phenomenon is usually known in economic literature as the Dutch Disease (DD) [8].

\section{DUTCH DisEASE SYMPTOMS IN MACAU}

Conventionally, the DD associates the increase in foreign currency resulting from soaring revenues of a country's exports of natural resources, after discovering a new natural resource ("resource boom"), or new applications for the existing ones, with deindustrialization pressures (refer to [9] for a detailed analysis of the DD mechanism).

However, this currency inflow can also be sourced by FDI, 
foreign aid [10] or even GT revenues, as it is proposed in this paper. Presently, the GT sector is a major pillar of Macau's economy with the exports of services resulting from the expenditure of non-residents in the domestic market representing more than $105 \%$ of Macau's GDP in 2011 (data source:[4]). Simultaneously, Macau has also been showing signs of a declining manufacturing sector as the share of the manufacturing production in total GDP went from almost $10 \%$ in 2000 to less than $1 \%$ in 2010 (data source:[6]).

As Macau started showing some symptoms of the DD, we corroborated this suspicion by performing an empirical assessment of that economic phenomenon in the territory, substantiating and consolidating as well our preliminary findings about the DD's existence in Macau ([11], [12]).

In effect, the sustainability of Macau's GT dependence has been in the center of local concerns (refer to [13], which expressed the concern about Macau's economic volatility). Therefore, identifying accurately the underlying economic phenomenon of Macau's economic reality should contribute to an understating of the expected accompanying long term effects and, most of all, to design an appropriate strategy to downsize the potential adverse outcomes.

\section{DutCh DisEASE RELATED Literature}

\section{A. Reference Theory: The Core Model}

Corden and Neary presented in [9] what came to be recognized as the "core model" of the DD economics. The two authors considered a framework of a small open economy producing two tradable goods and one non-tradable (NT) good, where the two co-existing tradable goods consisted of a booming and a lagging good (usually, manufacturing). These three goods were assumed to be produced by two primary factors: inter-sectoral perfectly mobile labor and sector-specific capital. Both these factors of production were considered to be internationally immobile.

This model also considered that the price of the two tradable goods was exogenously given by international markets, and that the NT good's price was determined domestically by supply and demand.

Under this framework, Corden and Neary [9] asserted that a resource boom in a small open economy should origin two effects: the resource movement effect (RME) and the spending effect (SE).

The RME occurs when, after the resource boom, the marginal product of labor rises in the booming sector, and there is a shift in labor into this sector from the other two remaining sectors. This shift has two major consequences: a contraction of the lagging sector ("direct deindustrialization") and excess demand for NT goods, which promotes an increase in the price of this type of goods (i.e., real appreciation, given that the two tradable goods' prices are assumed to be internationally determined).

The SE arises when part of the domestic extra income, resulting from the resource boom, is spent and thus raises the relative price of the NT goods (real appreciation). As a consequence, there will be a shift in labor to the NT sector and further contraction of the lagging sector ("indirect deindustrialization").

The core model also assumed perfectly flexible real wages.
Therefore, as noted by [14], both the RME and the SE should rise the wage in terms of the lagging sector (and also in nominal terms), as a result of the increased demand for labor.

In summary, it is possible to establish the following unambiguous DD symptoms: real exchange rate's appreciation, nominal wage increase, and decrease in the lagging sector's labor and output, that is, deindustrialization, which unquestionably implies a decrease in that sector's exports [15].

\section{B. Empirical Studies}

The DD empirical literature essentially covers two kinds of studies: single-country and cross-country analyses. There are several studies analyzing the effects of the DD in a single country, such as the analysis performed by [16] for the case of Russia, which is regarded as one of the major producers of natural resources.

However, performing a diagnosis of the DD's presence in a specific economy requires a careful analysis, not only because other mechanisms rather than those associated with a large surge in foreign currency inflows (particularly, a resource boom) might cause the same symptoms of the DD (as the Balassa-Samuelson effect ${ }^{1}$ ), but also because the surrounding national and international contexts might hide or exacerbate the DD process. Many authors prefer to carry cross-country approaches in order to empirically detect the DD.

One of the major references concerning DD empirical cross-country analysis is [18], where the authors found evidence that countries with natural resource abundance tend to experience a slower growth pace.

Although literature about the DD in the generic case the open economy is extremely vast, DD studies in tourism economies are still embryonic, from a formal point of view, and even scarcer from an empirical perspective. One of the most commonly cited cases regarding the empirical approach to the DD's presence in tourism-oriented countries is [19]. This study ([19]) examined the new recreational use of the coastal natural resources of two heavily tourism-oriented Spanish regions, the Balearics and the Canary Islands, which had experienced a tourism boom in the early 1960s, and concluded that both regions showed signs of the DD.

Conversely, [20] provided an empirical analysis to assess the long-run danger of a DD effect in tourism-dependent countries named "Beach Disease Effect" in [20]. This analysis concluded that there was no reason to fear a "Beach Disease Effect", at least in the long-run, and that most of the indirect effects of tourism should operate through physical and human capital channels.

As a result, contrary to raw materials extraction, tourism exploitation should spur the development of strong physical and human capital bases (tourism infrastructures such as buildings, airports, roads and school enrolment), and the initial fear of the DD's harmful presence might not materialize. However, of course, the national and international economical, political, and social circumstances surrounding each reality make it unique and, therefore, the

\footnotetext{
${ }^{1}$ The Balassa-Samuelson effect refers to the mechanism that occurs during the catching-up process, through which the faster relative productivity gains in the tradable sector generate an appreciation of the real exchange rate [17].
} 
specific context of each case should be assessed complementarily to the diagnosis.

\section{Recent Findings about Macau}

As a result of the GT boom, the concern about the potential presence of the DD in Macau arose. While this territory has been exhibiting some DD symptoms (namely, deindustrialization signs) for the past years, not until very recently the association of this economic phenomenon with Macau's GT reality has been noticed in newly published literature, such as [21] or [22].

In addition, we are only aware of one study ([23]), prior to our preliminary results ([11] and [12]), where the DD's detection in Macau was given considerable attention. Therefore, we consider that supplementary empirical evidence using a different approach and estimation method, a longer data span, and alternative variables seems imperative in order to assess the effective presence of the DD in Macau.

The consolidation of an empirical model to assess the presence of the DD phenomenon in Macau is in our view a required step to evaluate the potential long term effects for Macau's economy and, thus, contribute insightfully to the discussion about Macau's sustainability.

\section{AN EMPIRICAL MODEL FOR THE DUTCH DiSEASE IN MACAU}

\section{A. Framework and Hypotheses}

Following Corden and Neary's work ([9]), we adopted a framework of a small open economy divided into three distinct sectors: a NT sector (Services) and two tradable sectors (GT and Manufacturing - booming and lagging, respectively). In particular, the GT sector is considered to comprise the gaming activities and all services related to tourism, such as accommodation, restaurant services, entertainment and cultural activities.

Considering the GT boom characterized by a surge of foreign currency inflow resulting from both shocks in supply and demand of GT, and given the unambiguous combined outcomes of the RME and the SE of the $\mathrm{DD}$, the following testable hypotheses emerge directly:

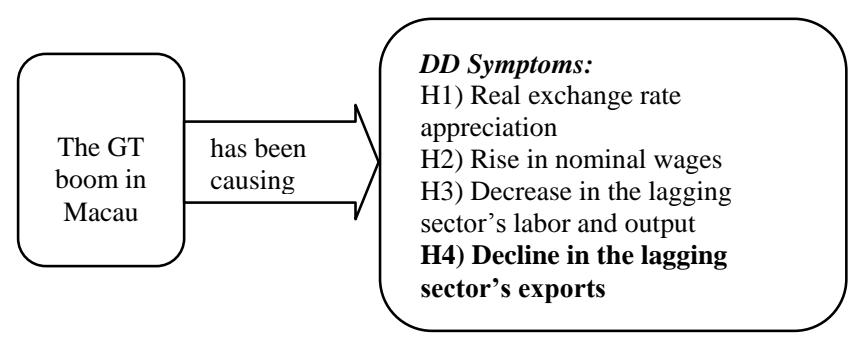

Fig. 1. Testable hypotheses

In the case of Macau, real exchange rate movements are expected to be different from those of a common small open economy as Macau's currency is under a fixed exchange rate regime due to the adoption of a Currency Board Arrangement under which the Pataca (i.e., Macau's currency) has been pegged to the Hong Kong Dollar since 1983, which in turn, has been linked to the United States Dollar, at a reference rate [24]. Given the specificities behind Macau's real exchange rate we chose not to test for $\mathrm{H} 1$ ).
In line with the analysis of [9], we give primacy to the variables expressed in real values, because, having been adjusted for the price changes, real variables' evolution should only reflect the changes in physical units and, by these means, enable a more accurate analysis. Hence, we don't test for $\mathrm{H} 2$ ),

In terms of sectoral impact, the unambiguous signs of the DD in Macau after the GT boom should be a decline in the output of the lagging sector and a fall in the exports of the same sector.

The overall impact of the GT boom should be stronger in the exports of the lagging sector compared to that impact in the output of that sector, since the fall in those exports should result not only from the expected decline in the output of the lagging sector, but also from the pressure of domestic demand for the lagging good due to the spending effect, provided that the lagging good is normal.

As a result, we consider that in order to effectively corroborate the presence of the DD phenomenon in Macau we should test the impact of $G T$ indicators on the real domestic exports of goods (that we denote by $D E X G$, henceforth), and which were used to proxy the exports of the lagging sector. Hence, in this paper we test specifically for H4).

\section{B. Methodology and Model Specification}

In order to capture the DD's effects in Macau, we focused on the relationship between the GT boom proxy variables and Macau's real domestic exports of goods $(D E X G)$, i.e., the exports of goods produced in Macau other than services, adjusted by the exports of goods deflator. Therefore, this variable serves as dependent variable. Macroeconomic literature is consensual that a country's exports are a function of its importers income and of price competitiveness. Hence, function (1) represents the initial DEXG function considered.

$$
D E X G=f(F G D P, T O T)
$$

where $F G D P$ stands for foreign gross domestic product and represents the GDP of the Group of Seven (G7). TOT corresponds to the terms of trade computed as the ratio of the exports of goods deflator (goods produced domestically) to the imports of goods deflator (goods produced abroad). Therefore, this variable is included in the model as an explanatory variable to capture the price effect.

Considering our primary purpose of assessing the DD's presence in Macau, the initial function (1) was extended in order to include variables as to proxy the GT boom until obtaining function (2).

These additional variables include the completion of buildings in the territory $(C O M B)$, the ratio of the expenditure of non-residents in the domestic market (mainly in gaming and accommodation) to total exports [ENR(\%TE)], and labor in the GT sector ( $L G T)$, which mainly refers to labor in hotels, restaurants, and recreational, cultural, and gaming services.

While $C O M B$ serves as a proxy to FDI and $E N R(\% T E)$ approximates the local spending of Macau's visitors, $L G T$ is considered as an additional proxy of the GT boom as a whole.

We provide a full description of the variables used, their sources and transformation procedure in Table II in the 
Appendix.

$$
D E X G=f[F G D P, T O T, C O M B, E N R(\% T E), L G T]
$$

To perform the empirical estimations, we collected quarterly figures from 1998 to the first quarter of 2012. Given the use of quarterly data, each individual series was seasonally adjusted, except for FGDP whose records had already been seasonally adjusted by the respective source.

The overall equations are specified in the log-difference ( $\Delta \ln$ f) form; thus, the final variables represent an approximation to quarterly growth rates. The final variables were also tested for stationarity having passed the Augmented Dickey-Fuller (ADF) unit root test.

The econometric approach adopted was to estimate distributed-lag models with four lagged periods, since we used quarterly data, by Ordinary Least Squares (OLS), where initially all variables at period $t$ and their respective lags from period $t$ - 1 to period $t$ - 4 were included.

Initially, we considered a model where the $D E X G$ depended only on the standard explanatory variables FGDP and TOT. Then, in order to emphasize and control for the contribution of each GT boom proxy to the estimation, we gradually introduced and combined those variables until estimating a final model where all GT boom proxy variables considered (COMB, LGT, and ENR $(\% T E))$ were included. This last model is illustrated in equation (3), where the residuals at period $t$ are denoted by $\varepsilon_{t}$.

$$
\begin{aligned}
& \Delta \ln \left(D E X G_{t}\right)=\beta_{0}+\sum_{l=0}^{4} \beta_{1, l} \Delta \ln F G D P_{t-l}+\sum_{l=0}^{4} \beta_{2, l} \Delta \ln T O T_{t-l}+ \\
& \sum_{l=0}^{4} \beta_{3, l} \Delta \operatorname{lnCOMB} B_{t-l}+\sum_{l=0}^{4} \beta_{4, l} \operatorname{\Delta lnENR}(\% T E)_{t-l}+ \\
& \sum_{l=0}^{4} \beta_{5, l} \Delta \ln L G T_{t-l}+\varepsilon_{t}
\end{aligned}
$$

For each estimation performed, we dropped insignificant independent variables, through sequential elimination, to correct for autocorrelation. The resulting final specification, which included all GT proxy variables, is illustrated by equation (4).

$$
\begin{aligned}
& \Delta \ln \left(D E X G_{t}\right)=\beta_{0}+\beta_{1,1} \Delta \ln F G D P_{t-1}+\beta_{2,0} \Delta \operatorname{lnTOT} T_{t}+ \\
& \beta_{3,1} \Delta \ln C O M B_{t-1}+\beta_{4,0} \Delta \ln E N R(\% T E)_{t}+\beta_{4,3} \Delta \ln E N R(\% T E)_{t-3}+ \\
& \beta_{4,4} \Delta \ln E N R(\% T E)_{t-4}+\beta_{5,4} \Delta \ln L G T_{t-4}+\varepsilon_{t}
\end{aligned}
$$

The results of the estimations performed are displayed in Table I, and the final model that we selected corresponds to equation (4). This model selection was based on the best estimation results obtained and the chosen model was subjected to a range of tests to verify OLS assumptions.

This empirical study's hypothesis is based on the DD mechanism described above. Therefore, we expect that the coefficients for the variables that proxy the $G T$ boom are negative. In other words, our hypothesis is that the overall coefficients for $C O M B, E N R(\% T E)$, and $L G T$ are negative. Moreover, the consensus view for the export function is that income elasticity is positive and price elasticity is negative. Therefore, we anticipate a positive coefficient for FGDP and a negative coefficient for TOT.

\section{Results and Interpretation}

The several estimations performed are displayed in Table I, where column (vii) corresponds to the final estimation selected, i.e., to equation (4).

We can conclude, by analyzing this table, that including additional DD indicator variables continuously improved the estimations. All the coefficients expressed in these equations are significant at the usual $5 \%$ and $10 \%$ levels of significance, and estimates are identical across all variables with respect to the coefficients' signs.

As far as income and price effects are concerned they confirm the traditionally expected positive and negative signs, respectively; showing that Macau's domestic exports of goods are extremely sensitive to the income level of this territory's trade partners, and also evidencing that an improvement in Macau's terms of trade would certainly hurt the domestic exports of goods.

All GT activity variables have negative and significant coefficients, except for the case of $E N R(\% T E)$ in periods $t-3$ and $t-4$, which shows positive signs. Yet, the overall impact of this variable on $D E X G$ is still negative. Hence, the hypothesis that coefficients for the variables $C O M B$, $E N R(\% T E)$, and $L G T$ would be negative is confirmed and, by means of this, the presence of the DD in Macau is diagnosed. In short, empirical evidence seems to confirm this study's initial hypothesis that the GT boom in Macau has been causing DD symptoms; specifically, a decline in this territory's lagging sector's exports of goods (Fig. 1).

\section{Proposed Management of the Dutch Disease IN MACAU}

Although the DD phenomenon is associated with harmful consequences for the traditional industrial sector of a small open economy, in our view, the GT boom in Macau might bring adverce economic consequences for the territory if the excessive economic reliance on GT revenues constrains the territory's long-run economic performance.

Therefore, we believe that adequate management of the GT revenues should aim to shield Macau's economy against the long-run adverse effects of the dependence on GT revenues. As a result, we are in accordance with those authors (such as [25]) who suggest that resource abundant countries should pursue good investment policies and the promotion of good education.

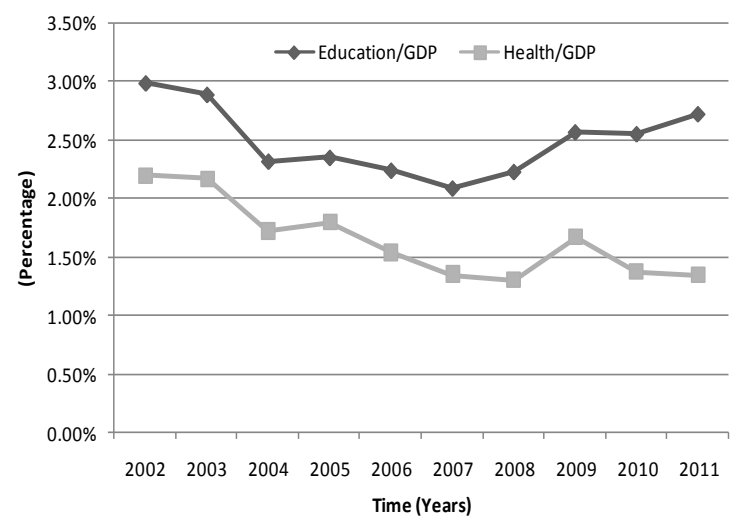

Fig. 2. Macau's public expenditure on education and health as a percentage of GDP: 2002-2011 
TABLE I: OLS ESTIMATES: DEPENDENT VARIABLE - $\Delta \mathrm{LN}(\mathrm{DEXG})$

\begin{tabular}{|c|c|c|c|c|c|c|c|}
\hline & (i) & (ii) & (iii) & (iv) & (v) & (vi) & (vii) \\
\hline Const & $\begin{array}{c}-0.093 * * \\
(-4.815)\end{array}$ & $\begin{array}{c}-0.082^{* *} \\
(-3.73)\end{array}$ & $\begin{array}{c}-0.090^{* * *} \\
(-4.829)\end{array}$ & $\begin{array}{l}-0.086^{* *} \\
(-4.808)\end{array}$ & $\begin{array}{c}-0.087 \text { ** } \\
(-5.056)\end{array}$ & $\begin{array}{l}-0.063^{* * *} \\
(-3.264)\end{array}$ & $\begin{array}{l}-0.068^{* *} \\
(-3.570)\end{array}$ \\
\hline$\Delta \ln [$ FGDP] & & $\begin{array}{l}8.96 * * \\
(3.23)\end{array}$ & & & & & \\
\hline$\Delta \ln \left[\mathrm{FGDP}_{1}\right]$ & $\begin{array}{c}12.721 * * \\
(5.029)\end{array}$ & & $\begin{array}{c}11.829 * * \\
(4.796)\end{array}$ & $\begin{array}{c}13.351 * * \\
(6.306)\end{array}$ & $\begin{array}{c}12.981 * * \\
(6.296)\end{array}$ & $\begin{array}{c}12.473 * * \\
(6.087)\end{array}$ & $\begin{array}{c}12.260^{* *} \\
(6.068)\end{array}$ \\
\hline$\Delta \ln \left[\mathrm{FGDP}_{2}\right]$ & & $\begin{array}{l}8.15 * * \\
(2.94)\end{array}$ & & & & & \\
\hline$\Delta \ln [\mathrm{TOT}]$ & $\begin{array}{c}-1.534 * * \\
(-3.941)\end{array}$ & $\begin{array}{l}-1.09^{* * *} \\
(-2.54)\end{array}$ & $\begin{array}{c}-1.580 * * \\
(-4.205)\end{array}$ & $\begin{array}{c}-1.101 * * \\
(-3.015)\end{array}$ & $\begin{array}{c}-1.397 * * \\
(-4.363)\end{array}$ & $\begin{array}{c}-1.085 * * \\
(-3.122)\end{array}$ & $\begin{array}{c}-1.376^{* *} \\
(-4.450)\end{array}$ \\
\hline$\Delta \mathbf{l n}\left[\mathrm{TOT}_{-2}\right]$ & & $\begin{array}{c}0.901 * * \\
(2.08)\end{array}$ & & $\begin{array}{l}0.599 * \\
(1.686)\end{array}$ & & $\begin{array}{l}0.590^{*} \\
(1.745)\end{array}$ & \\
\hline$\Delta \mathbf{l n}\left[\mathrm{COMB}_{-1}\right]$ & & & $\begin{array}{c}-0.034^{* * *} \\
(-2.293)\end{array}$ & & $\begin{array}{c}-0.026^{* *} \\
(-2.376)\end{array}$ & & $\begin{array}{c}-0.023^{* *} \\
(-2.108)\end{array}$ \\
\hline$\Delta \mathbf{l n}\left[\mathrm{COMB}_{2}\right]$ & & & $\begin{array}{l}-0.029^{*} \\
(-1.805)\end{array}$ & & & & \\
\hline$\Delta \ln [\operatorname{ENR}(\% \mathrm{TE})]$ & & & & $\begin{array}{c}-1.701 * * \\
(-4.311)\end{array}$ & $\begin{array}{c}-1.699 * * \\
(-4.452)\end{array}$ & $\begin{array}{c}-1.851 * * \\
(-4.859)\end{array}$ & $\begin{array}{c}-1.818 * * \\
(-4.877)\end{array}$ \\
\hline$\Delta \ln \left[\operatorname{ENR}(\% \mathrm{TE})_{3}\right]$ & & & & $\begin{array}{c}0.739 * * \\
(2.036)\end{array}$ & $\begin{array}{l}0.675^{*} \\
(1.931)\end{array}$ & $\begin{array}{l}0.644 * \\
(1.851)\end{array}$ & $\begin{array}{l}0.591^{*} \\
(1.738)\end{array}$ \\
\hline$\Delta \ln \left[\operatorname{ENR}(\% \mathrm{TE}) \_4\right]$ & & & & $\begin{array}{c}0.773 * * \\
(2.182)\end{array}$ & $\begin{array}{c}0.784 * * \\
(2.276)\end{array}$ & $\begin{array}{c}0.958^{* *} \\
(2.767)\end{array}$ & $\begin{array}{c}0.944 * * \\
(2.765)\end{array}$ \\
\hline$\Delta \ln [\mathrm{LGT}]$ & & $\begin{array}{c}-0.927^{*} \\
(-1.91)\end{array}$ & & & & & \\
\hline$\Delta \ln \left[\mathrm{LGT}_{-4}\right]$ & & & & & & $\begin{array}{c}-0.865^{* *} \\
(-2.376)\end{array}$ & $\begin{array}{c}-0.752 * * \\
(-2.073)\end{array}$ \\
\hline $\begin{array}{l}\text { Observations } \\
\text { Adj. R } \\
\text { Autocorrelation LM } \\
\text { Test (LMF) } \\
\text { Durbin-Watson }\end{array}$ & $\begin{array}{c}52 \\
0.429 \\
1.878\end{array}$ & $\begin{array}{c}52 \\
0.442 \\
2.263\end{array}$ & $\begin{array}{c}52 \\
0.470 \\
1.220\end{array}$ & $\begin{array}{c}52 \\
0.603 \\
0.448\end{array}$ & $\begin{array}{c}52 \\
0.625 \\
0.283\end{array}$ & $\begin{array}{c}52 \\
0.640 \\
0.500\end{array}$ & $\begin{array}{c}52 \\
0.650 \\
0.338\end{array}$ \\
\hline
\end{tabular}

In the case of Macau, we assert that channeling the GT revenues to education and health should be a priority of the strategy chosen to manage the DD in the territory, as it would promote the enhancement of the territory's Human Capital.

Fig. 2 (data sources: [4] and [7]) depicts Macau's public expenditure on education and health as a percentage of GDP, for the period 2002-2011. The public expenditure on health as a share of Macau's GDP shows an overall decreasing path, and the same is true for Macau's public expenditure on education as a share of GDP until 2007, year after which this ratio started a recovering path. Nevertheless, despite this recent increasing trend, in 2011, the share of Macau's public expenditure on education on GDP hadn't yet achieved the $3 \%$ level recorded in 2002.

Given these figures, we suggest that part of the GT revenues should be channeled to strengthen local capacities (explicitly, education and health). This recommendation is based on the assumption that investing GT revenues in local competences will prepare Macau for the event of a decrease in the source of the GT boom (tourists' visits and their local spending), strengthening this region against adversity.

In brief, we consider that increased quality education and health will not only lead to enhanced Human Capital and, consequently, to economic efficiency, but will also prepare Macau's active population for the likelihood of a decline on its GT activity, since a skilled and flexible workforce will have alternative professional choices.

\section{CONCLUSION}

Under our framework, gaming liberalization, readily followed by the removal of travel barriers between Mainland China and Macau, prompted the GT boom in Macau. The supply shock caused by the arrival of new GT operators, as well as by the expansion of the existing one, was instantaneously fueled by a demand shock in the same sector. This situation of positive shifts in demand and supply for GT characterizes the GT boom in Macau.

This post-2002 gaming era in Macau, marked by the GT boom, was accompanied by signs of deindustrialization and the suspicion of the DD's presence in this region. We corroborated this suspicion by estimating an empirical domestic export of goods growth rate model, which provided convincing evidence about the presence of this disease in that territory.

In hand with the knowledge about the economic phenomenon behind the recent developments in Macau's economy, the contribution to the discussion among scholars and economic agents regarding the sustainability of this region's economy becomes more assertive. We believe that the main problem with the existence of the DD in Macau is that, in case of losing its gaming privileged position; there isn't presently an alternative activity capable of supporting the territory.

Therefore, we consider that directing the GT revenues to develop high quality education and health systems will lead to enhanced efficiency in the economy as a whole through a 
strong Human Capital base, and will as well prepare Macau's active population for an eventual decrease in the GT activity, as skilled workers will have the flexibility to embrace alternative activities.

In summary, we consider that the most favorable strategy to manage the DD in Macau should represent the optimal use of GT revenues, giving priority to investment decisions that result in the creation of lasting value, not uniquely based on those GT revenues. By means of this, in face of an eventual decrease in GT revenues, Macau should have generated more wealth than before and should benefit from the proceeds of former GT revenues investments.

\section{APPENDIX}

TABLE II: DESCRIPTION OF THE VARIABLES

\begin{tabular}{ll}
\hline Variable & \multicolumn{1}{c}{ Description } \\
\hline & $\begin{array}{l}\text { Designation: Macau's Real Domestic Exports of Goods } \\
\text { (Million MOP) } \\
\text { Sources: [4], [6], and [26] }\end{array}$
\end{tabular}

Details and Transformation: This variable represents the ratio of Domestic Exports of Goods, expressed at current prices, to the price of total Exports of Goods, which was $D E X G \quad$ captured through the deflator of total Exports of Goods. Each individual series was seasonally adjusted through X-12-ARIMA.

Additional Notes: This variable refers exclusively to the domestic exports of goods, and excludes not only Macau's re-exports of goods, but also the exports of services, which are mainly driven by $G T$ services.

Designation: Gross Domestic Product of G7 (Millions of US dollars, volume estimates, fixed PPPs, OECD reference year, annual levels)

Source: [27]

FGDP Details and Transformation: The series was seasonally adjusted by the source.

Additional Notes: G7 refes to the following 7 countries: Canada, France, Germany, Italy, Japan, United Kingdom and United States.

Designation: Terms of Trade - Index

Sources: [4] and [6]

Details and Transformation: This variable represents the ratio of the price of total Exports of Goods to the price of total Imports of Goods, which were captured through the deflators of total Exports of Goods and total imports of goods, respectively. Each individual series was seasonally adjusted through X-12-ARIMA.

Designation: Completion of Buildings $\left(\mathrm{m}^{2}\right)$ - Gross Floor

Area

COMB Source:[6]

Details and Transformation: This series was submitted to seasonal adjustment through X-12-ARIMA.

Designation: Ratio of the Expenditure of Non-Residents in the domestic market to Total Exports $(\%)$ - percentage Source: [4]

Details and Transformation: This variable represents the

$E N R(\% T E)$ ratio of total expenditure of non-residents in the domestic market at current prices (which includes gaming, accommodation and others), to total exports of goods and services at current prices. Each individual series was seasonally adjusted through X-12-ARIMA.

Designation: Labor in the GT sector ('000)

Source: [6] Details and Transformation: This variable represents the
employed population in hotels, restaurants and similar activities; and, in recreational, cultural, gaming and other services. This series was seasonally adjusted through X-12-ARIMA.

\section{REFERENCES}

[1] DICJ. Macau Gaming History. (November 8, 2012.) Gaming Inspection and Coordination Bureau of Macao SAR Website. [Online]. Available: http://www.dicj.gov.mo/web/en/history/index.html.

[2] DICJ. Quarterly Gaming Statistics. (November 8, 2012). Gaming Inspection and Coordination Bureau of Macao SAR Website. [Online]. Available:

http://www.dicj.gov.mo/web/en/information/DadosEstat/index.html.

[3] DSEC, Direct Investment Statistics, Statistics and Census Service of Macao SAR Government, Macau, 2002-2010.

[4] DSEC, Quarterly Gross Domestic Product, Statistics and Census Service of Macao SAR Government, Macau, 2004-2012.

[5] J. Guo, "Macao's Tourism Industry and its Dependence on Mainland China," Journal of Global Business Management, vol. 7, no. 2, 2011.

[6] DSEC. Time Series Database. (2009-2012). Statistics and Census Service of Macao SAR Government Website. [Online]. Available: http://www.dsec.gov.mo/TimeSeriesDatabase.aspx

[7] DSEC. Yearbook of Statistics. Statistics and Census Service of Macao SAR Government. Macau. 2002-2011.

[8] D. Rutherford, Routledge Dictionary of Economics. New York: Routledge, 2002.

[9] W. M. Corden and J. P. Neary, "Booming Sector and De-industrialization in a Small Open Economy," The Economic Journal, vol. 92, pp. 825-848, December 1982.

[10] C. Ebrahim-zadeh, "Dutch Disease: Too much wealth managed unwisely," Finance and Development, vol. 40, no. 1, 2003.

[11] S. Mieiro and P. N. Ramos, "Dutch Disease in Macau: Diagnosis and Treatments," presented at the 9th Annual Conference of the European Economics and Finance Society, Athens, Greece, June 3-6, 2010.

[12] S. Mieiro, P. N. Ramos and J. Alves, "Dutch Disease in a Gaming Tourism Economy: The case of Macau," in Proc. IPEDR, 2012, 52, pp. 67-71.

[13] S. S. Chan, "Rationales and Options for Economic Diversification in Macao," AMCM Quarterly Bulletin , vol. 18, pp. 17-31, 2006.

[14] W. M. Corden, "Booming Sector and Dutch Disease Economics: Survey and Consolidation," Oxford Economic Papers , vol. 36, no. 3, pp. 359-380, 1984.

[15] A. M. Roca, "Dutch Disease and Banana Exports in the Colombian Caribbean, 1910-1950," presented at the 1998 Meeting of the Latin American Studies Association, Chicago, Illinois, September 24-26, 1998.

[16] N. Oomes and k. Kalcheva, "Diagnosing Dutch Disease: Does Russia Have the Symptoms?" IMF Working Paper, WP/07/102, pp. 1-8, 2007.

[17] V. Coudert, "Measuring the Balassa-Samuelson effect for the Countries of Central and Eastern Europe," Banque de France Bulletin Digest, vol. 122, pp. 23-43, 2004.

[18] J. D. Sachs and A. M. Warner, "Natural Resources and Economic Development: The curse of natural resources," European Economic Review, vol. 45, pp. 827-838, 2001.

[19] J. Capó, A. R. Font, and J. R. Nadal, "Dutch Disease in Tourism Economies: Evidence from the Balearics and the Canary Islands," Journal of Sustainable Tourism, vol. 15, no. 6, 2007

[20] M. Holzner, "Tourism and Economic Development: the Beach Disease?" The Vienna Institute for International Economic Studies Working Papers, vol. 66, pp. 1-30, 2010.

[21] L. Sheng and Y. Tsui, "A general equilibrium approach to tourism and welfare: The case of Macao," Habitat International, vol. 33, pp. 419-424, 2009.

[22] L. Sheng and Y. Tsui, "Foreign Investment in Tourism: The Case of Macao as a Small Tourism Economy," Tourism Geographies, vol. 12, no. 2, pp. 173-191, 2010.

[23] J. Y. Ke and C. W. Liu, Does Macao Suffer From Dutch Disease? An Empirical Studies on Macao's Gambling Booms, University of Macau, Department of Economics of the Faculty of Social Sciences and Humanities, Macau, 2008.

[24] J. W. Pao, "The Currency Board Arrangement and the Macao Experience," Macao Monetary Research Bulletin, Monetary Authority of Macau, vol. 9, pp. 35-50, 2003.

[25] T. Gylfason, "The International Economics of Natural Resources and Growth," Minerals \& Energy, vol. 22, no. 1-2, pp. 7-17, 2007.

[26] DSEC, Macao Economic Bulletin, Statistics and Census Service of Macao SAR Government, Macau, 1999-2012.

[27] OECD. Stat Extracts. (August, 2012). Quarterly National Accounts. OECD Web site. [Online]. Available: http://stats.oecd.org/ 


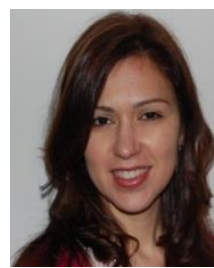

Susana Mieiro was born in Coimbra, Portugal, in 1976. She holds a Master degree with specialization in finance jointly awarded by Macau Inter-University Institute (current University of Saint Joseph), Macau, China and the Portuguese Catholic University, Portugal, in 2006. She received her Licentiate degree in Economics from the University of Coimbra, Portugal.

She is currently a D.B.A. candidate at the University of Saint Joseph, Macau, China. She holds three years of lecturing experience in the fields of Accounting and Management. Prior to that, she worked as a Financial Controller and Project Auditor. Her curren research interests include tourism economies, Dutch Disease economics, and the gaming phenomenon.

Ms. Mieiro is a full member of the "Ordem dos Economistas" (Association of Economists) in the chapter of Business Economics and Management.

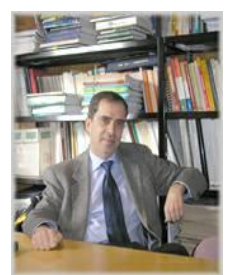

Dr. Pedro Nogueira Ramos was born in Figueira da Foz, Portugal, in the year of 1957. He got his Ph.D degree in Economics from the University of Coimbra, Portugal, in the year of 1992 .

He is currently a Full Professor at the University of Coimbra, Portugal. He is also the former head of the Portuguese National Accounts and he was a consultant of the Portuguese National Statistical Institute and of the Eurostat. He has been as well Pro-Rector of the University of Coimbra. He has several articles published in Portuguese and international journals and authored or edited several books and book chapters in his country. His current research interests include economic and social indicators, national and regional accounts, international macroeconomics, regional economics and economic geography.

Prof. Ramos is also the director of the Portuguese Review of Regional Studies.

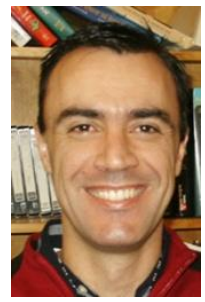

Dr. José Alves is an Associate Professor of Management at the Faculty of Business, Government and Social Work of the University of Saint Joseph, Macau. His major research interests include leadership and management in China. His research has been published in journals and conference proceedings, such as the Journal of Managerial Psychology, Human Resources Management Review, Career Development International, and International Journal of Leadership Studies. He has also presented papers at various conferences, including the Academy of Management, Iberoamerican Academy of Management, International Association for Chinese Management Research, and Eastern Academy of Management. 